\title{
E-POETRY: A MARCA DO HIPER-CONTEMPORÂNEO
}

Flavio Senra* Rafael Ottati

RESUMO: A fragmentação dos paradigmas e dos conceitos nas últimas décadas acarretou uma perceptível mudança epistêmico-subjetiva no indivíduo. Tal mudança igualmente alcançou o reino das Artes, de forma que um grupo de artistas, pessoas atreladas ao seu contemporâneo a ponto de problematizá-lo e de expô-lo, criaram obras inseridas no rótulo e-poetry, um novo gênero de poesia característico do século 21, visando reorganizar o fazer poético e as relações inter- e intrassubjetivas. Este artigo visa analisar a obra de um desses artistas, Jason Nelson, demonstrando como ela percebe e questiona o momento atual, envolto em uma ampla difusão técnica, científica e visual. Para tal, serão levantadas reflexões de Giorgio Agamben e de JeanFrançois Lyotard no que tange a definir o papel da Ciência na vida hodierna, assim como o aspecto visual da mesma.

PALAVRAS-CHAVE: Hiper-contemporâneo. Poesia eletrônica. Pós-modernidade.

\section{Introdução}

No que tange às artes de um modo (bastante) geral na contemporaneidade, percebe-se uma fluidez maior entre gêneros, linguagens e mídias, ou seja, uma fragmentação de paradigmas definidores e excludentes do que seria " $A$ " e "B" na esfera das artes. No caso do objeto literário, nota-se cada vez mais que analisá-lo tendo como parâmetro unicamente os trâmites literários se mostra uma metodologia insuficiente na era contemporânea.

É de conhecimento geral que entre o apagar das luzes do século 19 e o raiar do século 20 uma série de movimentos de vanguarda promoveram uma série de rupturas no que concerne ao fazer artístico, rupturas essas que, de formas distintas e em contextos variados, deixaram ecos que podem ser ouvidos de forma amplificada (e, por que não dizer, bakhtiniamente polifônica) ainda nos tempos presentes. A Literatura estabeleceu diálogos, explícitos ou não, com

\footnotetext{
"Universidade Federal do Rio de Janeiro. Imeio: fpsenra@gmail.com.

* Universidade Federal do Rio de Janeiro. Imeio: rafael.ottati@gmail.com. Bolsista da CAPES. 
outras formas de Arte. Tais inter-relações chegaram a um nível em que, no presente, é impossível estabelecer qualquer forma de crítica literária sem levar em consideração outros discursos que a Literatura possa trazer consigo.

O recorte estabelecido para 0 presente texto toma por base uma produção literária contemporânea que é um exemplo bastante apropriado desse terreno híbrido, transmidiático e trans-autoral: a e-poetry - ou, simplesmente, a poesia eletrônica. Esboçando uma definição simples (mas não simplória), podemos classificar a e-poetry como o resultado da combinação de tecnologia e poesia. Por mais óbvia que possa parecer essa definição, é a partir dela que um universo complexo se abre perante os olhos do leitor. Os poetas eletrônicos, multimidiáticos por excelência, delimitam como proposta fundamental de seu projeto literário o emprego de mídias das mais diversas sob um viés críticocriativo. Imagens, sons, movimentos, vídeo, interfaces de programas distintos, linguagens de programação, páginas da internet, linguagem não-verbal e verbal são alguns dos extensivos elementos de comunicação de que esses poetas podem dispor.

Deve-se levar em consideração que uma nova técnica será, de forma velada ou gritante, simultaneamente o agente causador, o fator sintomático e o corolário de uma crise de quaisquer formas previamente estabelecidas de representação cultural e social. Pierre Lévy (LÉVY, 1999) defende que novas formas de técnica são, potencialmente, geradoras de novas subjetividades e, principalmente, novas relações sociais. A forma como o campo artístico é afetado - e, concomitantemente, afeta - as novas formas de técnica é um fator que acentua essa questão de forma significativa.

Assim, abre-se o presente estudo: para demonstrar tais formações de novas subjetividades, recorrer-se-á às criações poéticas de um e-poet. Jason Nelson. Seu website, em que estão armazenados seus poemas eletrônicos, intitula-se jason.nelson's.digital.poetry.interfaces. - com os pontos, sem maiúsculas e sem espaços entre as palavras, denotando desde a abertura do sítio o caráter 
experimental e técnico de suas criações, uma vez que remete mais a uma lista de comandos de programação ou de itens quaisquer do que a uma oração tradicional da estrutura "sujeito-verbo-predicado" ou a uma frase "comum". Uma de suas obras será postas em foco no presente texto: Sydney's Siberia, e-poem marcado por um caráter de abertura, polifonia, infinitude e intrínseca conexão ao seu leitor. Para embasar este estudo, adicionalmente, os apontamentos de Giorgio Agamben e de Jean-François Lyotard serão valiosos. Através do conceito de contemporâneo, da dicotomia luz-trevas e do âmbito científico e visual, a poesia eletrônica de Nelson será analisada em vias de demonstrar parte dessa mudança subjetiva ocorrida, sem se poder precisar exatamente quando, ao longo das últimas décadas.

\section{O Contemporâneo: Ciência e Visão}

Para Giorgio Agamben, contemporâneo é aquele que está em "relação com o próprio tempo, que adere a este e, ao mesmo tempo, dele toma distâncias", ou seja, está em relação igualmente "dissociada" e "anacrônica" com seu próprio momento (AGAMBEN, 2010, p. 59). O filósofo parte da segunda das considerações intempestivas de Nietzsche, reinterpretando-a, já que ele percebe que aquele que é completamente contemporâneo ao seu tempo pertence a ele verdadeiramente, ainda que não coincida "perfeitamente com este" (Id., p. 58), nem tampouco esteja "adequado às suas pretensões" (Id., p. 58).

Sendo o homem fruto do seu tempo e do seu espaço, infere-se do recém-exposto que o homem de fato integrado ao seu momento temporal tensiona os limites deste. O abraçar de seu momento não o impede de igualmente abraçar um passado pelo qual se sente nostálgico ou um futuro o qual almeja ou teme. $O$ filósofo acrescenta à sua reflexão outra definição, em que afirma que:

contemporâneo é aquele que mantém fixo o olhar no seu tempo, para nele perceber não as luzes, mas o escuro. Todos os tempos são, para quem deles experimenta contemporaneidade, obscuros. Contemporâneo é, justamente, aquele que sabe ver essa obscuridade, que é capaz de escrever mergulhando a pena nas trevas do presente. (AGAMBEN, 2010, p. 62). 
Urge ressaltar que, neste ponto, as trevas não necessariamente significam os aspectos negativos do momento em que o artista está inserido. Agamben (Id., p. 63) recorre à neurofisiologia da visão para demonstrar que "a ausência de luz desinibe uma série de células periféricas da retina, ditas precisamente off-cells, que entram em atividade [...]". Por conta disso, continua o filósofo, o escuro acaba por se mostrar como "o resultado da atividade das off-cells, um produto da nossa retina". Indo além, o escuro "implica uma atividade e uma habilidade particular que, no nosso caso, equivalem a neutralizar as luzes que provêm da época para descobrir as suas trevas, o seu escuro especial", o qual, todavia, não pode ser "separável daquelas luzes".

Por conta do corpus literário deste artigo, mencionam-se as luzes para, ao mesmo tempo, aludir ao aspecto tanto puramente científico quanto estritamente visual da vida hodierna. A massiva divulgação científica e a sua legitimação ao longo dos séculos resultaram em um estilo de vida singular, em que o sujeito se percebe envolto por definições e criações de diferentes tecnologias em ascensão e reinvenção. Dos aparelhos eletrônicos gradativamente menores, mais leves e com mais funções, às notícias jornalísticas cheias de termos oriundos de jargões de vários campos da Ciência, de opiniões técnicas de especialistas e de resultados de pesquisas, a vida do indivíduo pós-moderno encontra-se simbioticamente atrelada à Ciência, ao fazer científico e a uma forma de pensar pragmática, calculista e matemática.

Esse avanço científico ganhou força e apelo a partir do Renascimento, em um momento que talvez se pudesse chamar de pré-modernidade. Francis Bacon, para usarmos como exemplo um intelectual desse recorte temporal, acreditava que a Ciência era sinônimo ou resultado do exercício de poder sobre a Natureza: para dominá-la, precisava-se entendê-la. Nos § I e X, dentre outros, de sua obra teórica Novum Organum -, o pensador defendeu a observação do agir da natureza para depois interpretar tais descobertas de forma a conseguir refazê-las em experimentos sob um método científico. Ao fim do processo, de acordo com a 
meta baconiana, o homem superaria a natureza, realizando - e melhorando - o que ela faz, já que o homem é "ministro e intérprete da natureza" (BACON, 1999 [1620], §1, p. 33.). Tais possibilidades são demonstradas na obra ficcional Nova Atlândida, em que o filósofo inglês, a partir daquilo que ele testemunha como acontecimento na natureza, acredita ser possível de ser praticado pelo homem. Como diversas conquistas científicas comprovaram ao longo dos séculos, Bacon não estava errado quando escreveu essa obra. Alguns exemplos que ilustram suas certezas - e que se tornaram realidade posteriormente - são: a dessalinização da água ${ }^{1}$, os transgênicos ${ }^{2}$, os cruzamentos de espécies animais ${ }^{3}$, as inúmeras formas de artificialização e mecanicação de elementos do mundo orgânico, promovidos como resultados "revolucionários" de décadas de intensa pesquisa científica 4 , além da criação de produtos através de artefatos inexistentes na época em que Bacon vivia, como o fogão (e o controle do fogo artificial, que hoje acontece com o gás butano), o papel e tecidos que igualmente não existiam na Europa ${ }^{5}$, dentre outros. Em suma, uma incrível projeção de conquistas dos séculos seguintes. A fé desse filósofo na ciência é incomensurável e alicerçou boa parte da mesma fé que o Homem veio a desenvolver, além de motivar os cientistas ao longo dos anos que se seguiram à publicação de ambas as obras.

Ao longo do século 18, por outro lado, com o início de um forte movimento intelectual e científico, surgiram intelectuais dos mais variados campos, dentre os quais Immanuel Kant, rotulando sua era de "Iluminismo" ou "Esclarecimento". Tais analogias relacionam-se diretamente com a questão da luz agambeana - embora metaforicamente - uma vez que Kant explicitamente afirma que:

\footnotetext{
1 "Temos também tanques, onde se extrai a água pura da água salgada". (BACON, 1627, p. 246.)

2 "Ainda por meios artificiais, tornamo-las [as plantas e as flores] maiores que o normal e tornamos os frutos maiores e mais doces e diferentes, no gosto, no aroma, na cor e na forma do produto natural". (Id., p. 247).

3 "Conseguimos artificialmente torná-los [os animais] mais fortes e mais altos que o normal da espécie e também, ao contrário, menores pela interrupção de seu crescimento [...] Descobrimos diversos cruzamentos que engendram espécies novas, e não estéreis, como pretende a opinião vulgar." (Id., p. 247-8).

4 "Mas, sobretudo, temos calores [produzidos artificialmente] que imitam o calor do sol e dos corpos celestes, passam por diversos graus de intensidade e que, por assim dizer, estão sujeitos a órbitas, ciclos e retornos periódicos [...]."(Ibid., p. 249)

5 "Temos ainda diversas artes mecânicas, que não possuís, bem como produtos obtidos por meio delas, como o papel, o linho, a seda, tecidos, delicados trabalho de penas de extraordinário brilho, tinturas excelentes e muitos produtos". (Ibid., p. 249)
} 
Esclarecimento [Aufklärung] a saída do homem de sua menoridade, da qual ele próprio é culpado. A menoridade é a incapacidade de fazer uso de seu entendimento sem direção de outro indivíduo. O homem é o próprio culpado dessa menoridade se a causa dela não se encontra na falta de entendimento, mas na falta de decisão e coragem de servir-se de si mesmo sem a direção de outrem. (KANT, 2010, p. 63).

Essa "menoridade" era, conforme o filósofo afirmou em outra obra, a "razão humana vulgar" (KANT, 2007), isto é, a atitude cotidiana não-reflexiva, geralmente baseada no senso comum e na tradição de costumes passados de geração a geração. Uma razão, pois, diferente da que Kant chama de "filosófica": seu objeto de estudo por excelência. Além disso, nota-se no trecho destacado que o filósofo alemão centrava suas preocupações quanto à prática diária das pessoas no convívio social, ou seja, naquilo que se faz em "direção de outro indivíduo". O caráter social do ser humano, portanto, é tema central em seu pensamento. $E$ para solucionar o imbróglio de que em uma sociedade tal há diversas pessoas com diferentes motivações, vontades e desejos, ele estipulou a primazia da Razão sobre as emoções. Com isso, o indivíduo torna-se inteiramente responsável por aquilo que pratica, conforme o trecho citado acima explicita ao afirmar que a menoridade seria culpa do próprio homem.

O nome de "Esclarecimento" adotado não apenas por Kant, mas por outros intelectuais de sua época, mostra-se adequado ao recorte temático proposto neste artigo, uma vez que se almeja analisar a obra de poetas que, por trabalharem com o estético, isto é, com a sensação, apreendem a realidade circundante de uma forma que o sujeito comum não atinge rotineiramente. $O$ resultado desses experimentalismos sensoriais desses artistas está enraizado no momento presente ao mesmo tempo em que projeta-se para possibilidades futuras, baseando-se tanto na visão - enquanto fonte de percepção do real e de entrada de informações no sujeito - quanto na Ciência - aquela que nos cerca com produtos, construtos e linguagem diferenciados.

Embora a Ciência tenha se posicionado ao longo dos séculos em um patamar de difícil acesso e, por conseguinte, compreensão por aqueles não iniciados em suas 
artes, Jean-François Lyotard percebe que na segunda metade do século 20 ocorre uma mudança de posicionamento frente a ela. A massiva divulgação científica acaba por descentralizar o saber que ela produz e defende, atingindo a uma parcela maior da população. Para o filósofo, "o saber científico não é todo o saber; ele sempre teve ligado a seu conceito, em competição com uma outra espécie de saber que, para simplificar, chamaremos de narrativo [...]" (LYOTARD, 2008, p. 12). Em outras palavras, ele percebe que o saber científico está atrelado ao discurso que se usa para descrevê-lo, defendê-lo e, mesmo, atualizá-lo. Sua legitimação ocorre através do discurso, da fala daqueles que a conhecem e estudam. Só que esse discurso ampliou-se ao ponto de descentralizar o saber científico, desatrelando-o dos conceitos absolutos e de difícil acesso em que se encontrava. Os jornais e revistas em que abundam termos e entrevistas científicos atestam este fato: o saber entrou em processo de globalização.

Por conta disso, Lyotard atenta para o fato de que já estava ocorrendo uma difusão de experts: profissionais altamente qualificados. $O$ saber não se encontraria apenas na ciência, mas em diversas outras áreas - o que necessitaria de indivíduos altamente qualificados na técnica necessária às funções atribuídas a seus cargos. Não era apenas "a Ciência", mas diversas "ciências", diversos usos do aspecto científico de produção de conhecimento. "O acesso às informações é e será da alçada dos experts de todos os tipos” (Id., p. 27). "A novidade", continua o filósofo francês, "é que, neste contexto, os antigos polos de atração formados pelos Estados-nações, os partidos, os profissionais, as instituições e as tradições históricas perdem seu atrativo" (Id., p. 27-8).

Como seria de se prever, a poesia (bem como as artes de um modo geral), não se manteria alheia a esta mudança ideológica e técnica. Sendo assim, os poetas da e-poetry trataram de aliar seus conhecimentos técnicos - de programação computacional, de criação hipertextual, de desenvolvimento de gráficos, dentre vários outros usos tecnicistas - à criação estética, dando luz assim a um produto artístico e sensorial totalmente inserido no tão científico e incrivelmente visual 
século 21. Um dos representativos desse lirismo eletrônico é Jason Nelson, autor de Sidney's Siberia.

\title{
Sidney's Siberia: o poema-pixel
}

Ao se adentrar a página oficial de Jason Nelson, tem-se um choque inicial: estão dispostos diversos blocos quadrangulares de informação na tela inicial. Cada um desses blocos possui um link para um dos poemas eletrônicos do autor, com alguns comentários do mesmo acerca de sua criação. Ao clicar em um deles neste caso, o que se intitula DigitalPoetry2: Mosaic [Poesia Digital 2: Mosaico] abre-se um frame na parte superior da tela explicando a proposta da poesia selecionada, onde lê-se:

\begin{abstract}
Detalhe: Cria infinitamente mosaicos interativos a partir de pequenos quadrados poéticos.

Não é a tecnologia tornando nossos cabos, nós e fluxos de dados ou nossas redes crescentes belos. Ao contrário, são histórias/poéticas, narrativas eternamente agrupadoras que transformam a inter/intranet em um mosaico vitalmente interessante. ......

Para explorar [esta poesia/experiência], navegue com o mouse para um quadrado que the agrade, clique, clique novamente, leia, contemple conexões e repita. ${ }^{6}$ (NELSON, [sd].)
\end{abstract}

Percebe-se inicialmente a dissociação da tecnologia do utilitarismo que a rege. $O$ autor estabelece que, neste caso, o avanço técnico não propiciará uma "vida melhor" no sentido pragmático deste termo, mas, sim, que seu uso será de cunho artístico. Tal modificação acarreta uma transformação do técnico, do nada - do ponto de vista da criação de produtos ou conhecimento de uso prático - para algo subjetivo. A arte em questão explicitará os elementos que dão suporte ao termo "internet", decomposto, de forma bem proveitosa (e bastante inovadora), em "inter-net", ou seja, em uma rede de ligação interpessoal, quais sejam, os elementos inter e intra das relações subjetivas. Estas relações são partes centrais

\footnotetext{
6 "Detail: Infinitely builds interactive mosaics from poetic tiles.

It is not technology making our wires, nodes and swimming data streams, our ever growing networks, beautiful. Instead it is the stories/poetics, the forever coalescing narratives that form the inter/intranet into a vitally compelling mosaic.

To explore, simply mouse-over/navigate to an appealing square, click and click, read, contemplate connections and repeat." Tradução livre. A partir deste ponto, todas as traduções extraídas do website do poeta serão traduzidas no corpo do texto livremente, mantendo-se o original em nota de rodapé.
}

Texto Digital, Florianópolis, v. 9, n. 2, p. 210-229, jul./dez 2013. ANO. ISSNe: 1807-9288 
da vitae, novamente destacada no texto com o termo "vitalmente": seus mosaicos poéticos são apreensões do real, além de produtos derivados da função interpessoal que rege a conexão empreendida entre o clique do leitor/espectador e o produto imaginado pelo artista.

A partir da explanação, abre-se o link do poema propriamente dito. Uma imagem surge com um texto informativo, que menciona que no século 19 pessoas fotografavam estranhos para, posteriormente, escreverem biografias fictícias sobre eles, de forma a inventar possíveis pilares sociais a partir dessas pessoas. O teor ficcional fica patente nesta curta explanação, assim como o motivo central desta obra: a tênue relação entre realidade e ficção. Ademais, sendo a informação - conjunto de dados mais difundidos na internet - algo que disserta, explica ou, previsivelmente, informa sobre alguém ou algum assunto, espera-se desta que tenha base na realidade. Daí que sites que emulam jornais eletrônicos enganem as pessoas nas redes sociais: tem-se pelo gênero jornalístico - frases curtas, explicativas, com poucos adjetivos, etc. - uma visão inerente à sua relação com o real sobre o qual ele informa e esta visão transforma-se em uma crença que ignora o fato explícito desses jornais-troça que são apenas criação fictícia.

Ainda a respeito dessa tela inicial, devemos ressaltar os elementos não-verbais componentes do "canto de abertura cibernética" desse poema. A imagem em questão. Vê-se uma parede de uma construção (aparentemente) portentosa, com um fino acabamento arquitetônico, com um quadro dependurado que nos mostra uma foto em preto-e-branco de um homem. Tanto pela paleta cromática da fotografia quanto pelas vestimentas do sujeito presente nela, percebe-se que a foto é bem antiga, possivelmente do fim do século 19 ou início do 20. Abaixo dessa imagem, um gigantesco número "22", em letras douradas, na parede. Em se tratando de e-poetry, devemos ter em mente que nenhum detalhe é em vão. A partir dos estudos de Annemarie Schimmel (1993), deve-se destacar que o número em questão, de acordo com a Numerologia, pode ter uma série de conotações distintas, algumas dignas de nota. Uma delas indica que o 22 é o 
número que representa o arquétipo do homem idealista, aquele que não se encaixa em parâmetros sociais vigentes e que vislumbra uma alternativa diferente para o futuro (e o presente) dos homens. É aquele que se sentirá, sempre, como o outro na organização societal, indo contra o status quo vigente. Suas maiores armas contra essa padronização são a inquietude mental, a criatividade, a inventividade, o pragmatismo e, acima de tudo, sua incompreendida genialidade.

O número em questão possui uma importância imensa no universo da numerologia. Sendo visto como um Número-Mestre, carrega consigo um princípio de equilíbrio universal, indicando uma fonte infinita de poder e de controle da realidade. É o número que melhor expressa a vontade de potência tipicamente nietzschiana, sobrepondo-se aos demais números por sua simbologia.

Se levarmos em consideração o caráter vanguardista da e-poetry, e as visionárias palavras do autor deste mosaico poético virtual que, em seu website, declara que a poesia eletrônica é o futuro da poesia como um todo, poderemos afirmar que a presença do número 22 na primeira parte do poema, com a simbologia numeróloga que ele carrega consigo, se não foi proposital, foi uma coincidência bastante oportuna, pois permite uma analogia com a proposta central da poética eletrônica em análise.

Outro traço digno de nota dessa modalidade poética a ser lida e vista é que as imagens dispostas, além de os textos sobrepostos a elas, possuem riscos, rabiscos, diagramas, círculos, rasuras, setas, e desenhos sugestivamente feitos como o mouse em um programa manipulador de imagens como o famigerado PaintBrush. Nota-se, logo, a presença tanto da mão que digita o texto, quanto da mão que o escreve de forma mais próxima do orgânico, se for levado em consideração que tentar desenhar ou escrever com o mouse se aproxima do redigir qualquer texto com uma caneta no papel. Esse caráter de duplicidade da expressão escrita, em que o homem e a máquina simbolicamente se fazem presentes, é um dos traços definidores do fazer poético eletrônico de Jason 
Nelson, e um dos indicadores da intrincada simbiose homem - máquina, humano e digital dos tempos contemporâneos, pilar central da e-poetry.

Dessa forma, a subversão da informação dos jornais-pastiche do século 19 explicada pelo texto verbal dessa tela, aliada aos recursos não-verbais presentes (a imagem, o número, os rabiscos, etc.), coloca-se como leitmotiv de Sidney's Siberia. Clicando-se na imagem informativa primária, tem-se um efeito de zoom, que faz com que sejam visíveis aos olhos do leitor/espectador os "tijolos" que constroem aquela imagem: incontáveis pixels. Clicando-se mais uma vez, o zoom traz os pixels mais para perto da visão e tem-se um choque de imediato: esses são, na verdade, blocos de poesia, conforme a figura abaixo comprova:

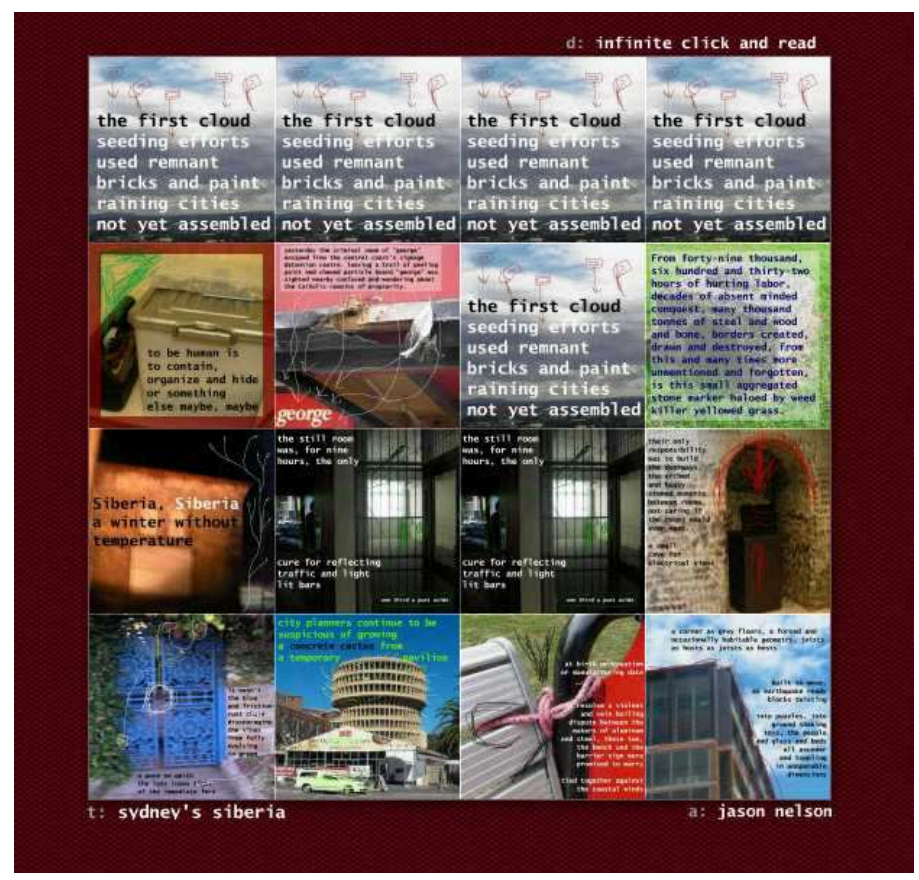

Figura 1: Os vários pixels.

Olhando-se atentamente para a figura acima, percebe-se que alguns dos poemas-pixels (ou seja, tanto texto quanto imagem) estão repetidos. Isso ocorre pelo fato de que, em escala de distanciamento, as palavras não podem ser lidas, de maneira que são as cores das imagens ao fundo que compõem a imagem maior. Como um zoom em uma rotineira foto de uma galáxia que vai exibir incontáveis sistemas solares, os quais, com mais zoom, revelar-se-ão compostos 
de infinitas estrelas e outros corpos celestes. Igualmente, um dos maiores construtos da Ciência revela-se profético para esta invenção artística: o microscópio. No caso, as lentes desse objeto revelam aos olhos aquilo que eles não têm poder para distinguir ou perceber. Jason Nelson com sua arte causa no espectador o mesmo assombro que o primeiro microscópio - ou o primeiro telescópio, objeto espacial desenvolvido com tecnologia óptica idêntica, porém obviamente mais avançada - causou naquele que olhou por ele, entrando em um mundo cotidianamente invisível. Mais uma vez, a metáfora das trevas e da luz de Agamben mostra-se acertada para o contexto analisado, já que é, sumariamente, de visão que se trata aqui. $O$ que se vê é essencialmente o que se acredita que exista. Em outras palavras, a visão é um sentido que determina parte do que se crê real, aquilo que há fora de nós - desde nossa própria pele, ao que a veste, ao que entra em contato com ela e assim por diante.

Podemos inferir desde já que o poema em questão tem como tema central uma visão fragmentada, múltipla e infinita do conceito tradicional de visão em si. Acima da caixa onde está disposto o poema eletrônico, localiza-se uma peculiar instrução: "infinite click and read" (algo como "clique eternamente e leia"). Essa orientação não poderia ser mais verdadeira, pois o leitor, diante de uma tela que contém alguma(s) estrofe(s) do interminável poema, poderá clicar em uma parte dela, seja ela qual for, e ser redirecionado a outra tela, com várias subdivisões em blocos, cada qual com uma microestrofe diferente do poema, e poderá escolher em qual clicar e seguir dessa forma, ad eternun. Compreendem-se, então, as inúmeras possibilidades de leitura e de construção do poema, dependendo da visualização escolhida pelo leitor eletrônico, ou seja, de acordo com o que foi escolhido de todos esses recortes para construir uma visão global personalizada do poema.

Esse caráter de interatividade com o poema, mais do que um exercício de fruição estética, mostra-se, de fato, como uma provocação estética: há internamente naquela imagem inicial toda uma série de pequenas imagens com palavras grafadas nelas. O leitor alcança-as clicando, isso é, o ato motor do espectador é o 
propiciador dessa revelação. A partir do momento em que o leitor decide não entrar no jogo do poeta, ele não saberá o que há ali dentro, escondido fora do alcance de seus olhos. Isso difere diametralmente da poesia tradicional, posto que se reconhece rapidamente um poema enquanto gênero textual justamente pela disposição formal-estrutural de seus parágrafos e frases, nomeados, respectivamente, estrofes e versos. No caso analisado, contudo, a poesia não existe se não houver cliques, de forma que, por mais eletrônica que seja esse $e$ poem, vemos que sem o toque humano, a poesia não existirá.

Além disso, percebe-se na figura 1 que há um quadrado avermelhado na segunda linha e na primeira coluna da esquerda. Esse quadrado é controlado pelo mouse. É ele que "encaixa" no poema-pixel que se quer aumentar a ponto de proporcionar uma leitura. Dos vários que existem dentro da referida obra de Jason Nelson, cita-se o seguinte:

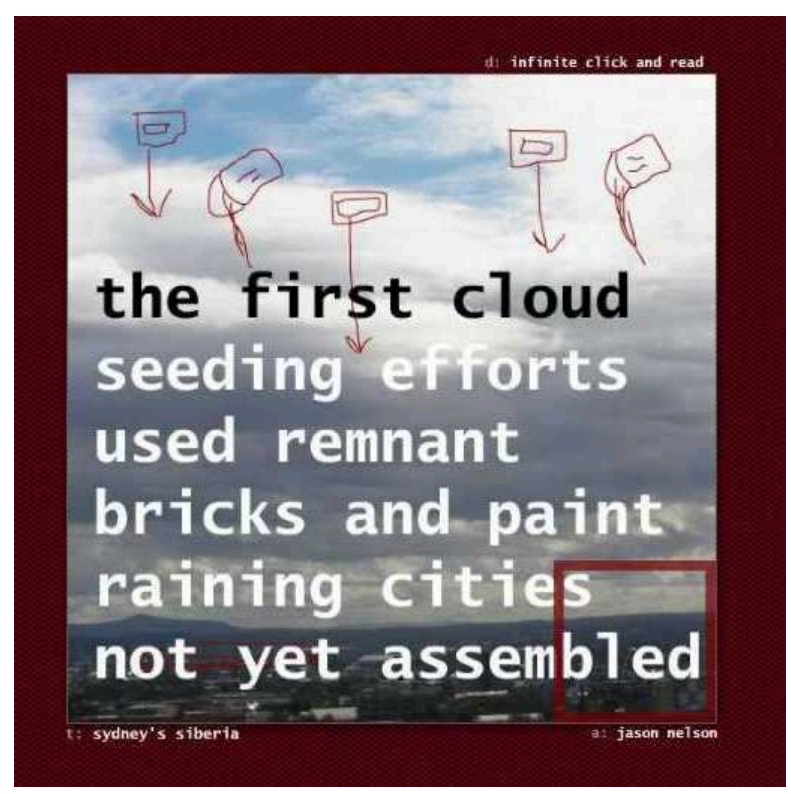

Figura 2: Um dos milhares de poemas-pixel.

Primeiramente, notam-se, nas nuvens, marcações malfeitas de cor avermelhada, possivelmente feitas em um programa convencional de edição de imagens, um traço recorrente na poética eletrônica nelsoniana, conforme já comentado no presente artigo. Em uma primeira análise, não se pode entendê-las 
completamente: aparentam ser meras formas retangulares com setas, balões de linguagem ou exemplos de listas de programas de processamento de texto. $\mathrm{O}$ segundo e o quinto desenhos, dispostos da esquerda para a direita, lembram vagamente um mouse, caso o leitor esteja disposto a decifrar e integrar esse discurso não-verbal ao verbal. As setas rabiscadas apontam para baixo, onde está o texto verbal poético-ficcional. Lendo-o, o eu-lírico eletrônico desta poesia nos explica - no limiar lexical deste verbo - que: "os primeiros esforços para semear nuvens usaram vestígios de tijolos e de tinta de cidades chuvosas ainda não montadas". Ora, os tijolos, assim como o termo "montados", estão intimamente atrelados à própria construção poética desta obra. São poemastijolos que compunham a imagem original daquele texto informativo.

Explorando mais essas palavras, percebe-se uma interessante confluência semântica entre o vocábulo "nuvens" e o verbo "semear". Sabe-se que este verbo indica a ação de se espalhar sementes pela terra, tendo como evidente objetivo o subsequente nascimento de plantas. Se este e-poetic persona almeja semear nuvens como se essas fossem plantas, imediatamente associamos o elemento céu (espaço onde ficam as nuvens, presente na imagem) com o elemento terra (no sentido de solo fértil em que sementes serão plantadas). Interessantemente, nota-se uma inversão da ordem natural dos ciclos biológicos, pois, ao invés da nuvem, através da chuva, ser o elemento a fomentar o crescimento de plantas no solo, é ela que será o elemento a ser semeado - pela mão do homem, possivelmente. Em um âmbito simbólico, em que as percepções e concepções "tradicionais" de biosfera são vistas de uma maneira muito mais plástica, nota-se, nesses versos, outra forma de inter-relação entre o Homem e o Espaço Orgânico (o Mundo).

Essas formas de inter-relação prosseguem, pois essas formas, tendo em mente que esses "primeiros esforços para semear nuvens", curiosamente, "usaram vestígios de tijolos e de tinta de cidades chuvosas ainda não montadas". Ou seja, empregando palavras oriundas de um campo semântico urbano, "tijolos", e "cidades", vemos que o eu-lírico faz referências ao elemento artificial, a aquilo que 
é simultânea e dicotomicamente o Magnus Opus do alquímico Homem Moderno e a implacável Nêmesis do Pós-Moderno: a metrópole, metonímia para o desenvolvimento não apenas urbano, mas tecno-científico, tecnocrático, biotécnico e ético-técnico da Humanidade. Logo, esses "vestígios de tijolos e de tinta" são as reduções minimalistas desse complexo de arranha-céus de concreto e vidro sendo, paradoxal e interessantemente, utilizados como sementes para semear nuvens. Todavia, devemos ressaltar que essas "sementes de concreto" são oriundas de "cidades chuvosas ainda não montadas", ou seja, de cidades que ainda são meros projetos, sonhos de um futuro, de um progresso, um planejamento arquitetônico-urbano a ser realizado pela mão do Homem. O fato dessas "cidades sonhadas" serem "chuvosas" reitera o ciclo e interação entre o espaço artificial (cidade) e o natural (os céus), já que, se o ser humano em suas projeções futuras imagina que as cidades receberão as chuvas que caem, logicamente, das nuvens, percebemos que as mesmas nuvens semeadas pelo homem pelas cidades a serem criadas pelos mesmos homens irão deitar suas próprias águas nas cidades que serviram como as sementes que originaram as próprias nuvens.

Essa interligação intrincada e ourobórica não soa absolutamente forçosa se levarmos em conta a comentada estruturação intersemiótica-interativa do poema "Sidney's Siberia". Esses versos aliados ao fato do leitor ter chegado a eles através de alguns cliques do mouse indicam o que está por vir: as grossas e brancas nuvens dessas imagens podem estar semeadas de poemas-tijolos. Notase no canto inferior direito que o quadrado vermelho controlado pelo mouse ocupa uma pequena fração da imagem. Isso significa que ele está enquadrando um pequeno trecho dessa foto de paisagem que pode ser aumentado através de um zoom assim que o leitor apertar novamente o botão direito de seu mouse. Ao fazê-lo, novamente inúmeros pixels aparecerão inundando esse grande quadrado emoldurado pelo fundo vermelho.

Disso resulta um retorno ao infinito, já que cada imagem de fundo de cada poema é composta por incontáveis poemas-pixels. A obra Sidney's Siberia, portanto, 
mostra-se como infinita e não-sequencial. Ambas as características relacionam-se à Ciência que, por sua vez, nos possibilitou perceber que somos parte de um Universo infinito e em constante crescimento, mas que, concomitantemente, possibilitou-nos produzir computadores com linguagens de programação intrinsecamente sequenciais. Isso representa um dos vários paradoxos do contemporâneo, percebidos apenas ao se afundar nas nuances da técnica (cada vez) mais sofisticada e mais presente na vida dos indivíduos pós-modernos, já que mesmo aparelhos celulares, televisões e videogames possuem, nos dias de hoje, dispositivos que tornam possível acessar a internet.

A poesia de Jason Nelson é complexa, por juntar imagens, texto informativo, hipertexto, espectador, visão, zoom, pixels e versos. Sua obra é, deve-se ressaltar, vastíssima: cada imagem é composta de diversos pixels e cada pixel é uma imagem com versos composta por vários outros pixels. Alguns desses mesmos pixels se repetem, conforme se vê na figura 1, mas é prática, lógica e cronologicamente inviável contar todos os que existem nesse grandioso poema: são infinitos, lembremos a instrução dada pelo próprio autor no topo da tela do poema ("clique infinitamente e leia"). Disso decorre mais uma questão importantíssima desse e-poem em particular e da e-poetry como um todo: sua relação simbiótica com o espectador. Não apenas sua existência depende da participação dele, como sua duração está conectada intimamente com o tempo gasto pelo leitor tanto nos cliques quanto na interação com o poema - e com a descoberta de mais e mais poemas-pixels.

A questão de inter/intrassubjetividade aflora para o primeiro plano, portanto. Sendo assim, pode-se afirmar que Sidney's Siberia tematiza a relação interpessoal em si, trabalhando a vontade e o desejo por ver e saber mais da parte do leitor de poesia, assim como ampliando o escopo de percepções sensoriais que decorrem de seu toque e de sua visão. Por conseguinte, esta obra poética está o mais alinhada possível com o momento contemporâneo de descoberta, através de novas e mais refinadas técnicas, de novos traços da 
própria subjetividade. Ela denuncia a existência sozinha, porém não solitária, que o ciberespaço criou hodiernamente.

Verdade seja dita, o ciberespaço espelha uma verdade da vida comum: o mundo, com avanço da ciência, foi ampliado. Isto é, suas dimensões espaciais mantêmse iguais, porém suas dimensões apreensíveis aumentaram. O microscópio revelou todo um micro-universo existente ao qual não tínhamos acesso antes. De igual maneira, o ciberespaço criou um micro-universo próprio, tecido por bits e bytes que igualmente são micro-formas do real, uma vez que são diminutas unidades de informação e/ou de dados. Carlos Drummond de Andrade já dizia, em seu "Poema de Sete Faces", que o mundo era vasto, porém mais vasto ainda era o seu coração - ou seja, o que ele se tornou, o que indica que o indivíduo, nesse cenário, percebe-se um ínfimo grão num universo composto por incontáveis grãos.

Semelhantemente a isso, o poema-pixel é apenas um grão dentro de um projeto infinitamente maior. Pequenez não significa desimportância, cabe ressaltar. Além disso, o poema que se revela feito de milhares de outros poemas também demonstra que o objeto-poema precisou adaptar-se aos novos tempos. Agora, uma poesia não é mais feita de versos e palavras - ela se faz de outras poesias. A infinitude de poemas de Sidney's Siberia revela os limites do objeto-folha e do objeto-livro em que figuram a poesia tradicional: em um mundo hiper-conectado, hiper-massificado, cheio de informações ocultas/invisíveis a olho nu, a poesiapixel mostra-se como uma criação hiper-contemporânea, pois extrapola os limites de sua época, esgarçando-os, revelando-os hiperbólica e explicitamente.

\section{Conclusão (?)}

A e-poetry mostra como a literatura na contemporaneidade busca caminhos para se adaptar à era dos recursos eletrônicos e da hipermídia, para não perder espaço diante de outras formas atrativas de comunicação, como e-books, blogs, chats, etc. Transbordando os limites do papel, percebe-se que a característica 
mais marcante da poesia digital é o seu caráter interativo: não se trata de um texto meramente disposto em uma tela. Frequentemente, a leitura do poema digital dependerá intrinsecamente dos cliques do leitor-navegador. Dessa forma, essa releitura digital da Teoria da Recepção mostra como o cursor de um mouse pode ser uma extensão do olhar do leitor que, ao construir seu próprio caminho de leitura, de link-verso para link-verso do poema eletrônico, entre páginasestrofe-em-html, torna-se, de fato, um co-autor do poema digital. Sobre essa interatividade do poeta eletrônico Jason Nelson afirma que o e-poem propicia esse nível de interação profunda com o leitor devido ao funcionamento intrínseco da poesia eletrônica. $O$ autor, na seção introdutória de seu site pessoal, afirma que esse tipo de ars poetica possui "uma estrutura arquitetônica, temática e cultural" que o sustenta ao mesmo tempo em que o abriga, fazendo-o, nos melhores moldes prosopopeicos e franksteinianos, "ganhar vida e procriar no seio digital" (NELSON, [sd]).

A escrita "tradicional", impressa na mídia papel - ou no objeto culturalmente solidificado livro - já se tornou para o homem uma forma de técnica naturalizada, convencionalizada e, até mesmo, obsoleta, se levarmos em conta o cenário atual dos e-books da e-poetry, tema central do presente texto. Em verdade, a poesia eletrônica, independentemente se apreciada ou rejeitada por determinado leitor, apresenta um dado inegável: o homem contemporâneo mantém um traço inerente a qualquer outra etapa de seu desenvolvimento cultural, que é a urgência de sempre inventar novas mídias, gerar novas formas de técnica e, consequentemente, atrelar a essas suas leituras do espaço em que vive, suas expressões de subjetividade, todos os seus múltiplos eus no mundo. Os meios audiovisuais e as tecnologias digitais são exemplos dessa mecânica.

Percebe-se na análise da obra Sidney's Siberia, de Jason Nelson, justamente esta imbricação de técnica com os múltiplos eus no mundo. A trans-subjetividade aflora para o primeiro plano da obra, demonstrando um novo criar poético que atende e tematiza parte das novas realidades subjetivas e existenciais do contemporâneo. A obra insere-se em uma vanguarda que abusa dos mais 
variados meios técnicos para provocar o leitor tornado ao mesmo tempo espectador e co-criador das obras. Retomando o conceito de luz e trevas agambeanos levantados no início do presente texto, podemos afirmar que, metaforicamente, a e-poetry conduz o leitor ao terreno das "trevas poéticoeletrônicas", em que, mediante o desligamento progressivo de todas as células periféricas da visão, novas formas de visão são possibilitadas: mais amplas, sinestésicas, intersemióticas, interativas e, incrivelmente, infinitas. Esse caráter de infinitude visual-visionária traduz a urgência de invenção e reinvenção de novas mídias e de novas identidades que define o Homem e lhe serve como força-motriz em seu viver-fazer no mundo.

Ainda que seja um projeto estético com uma quantidade bem significativa de adeptos, a poesia eletrônica ainda tem seu caráter marginal, mesmo na era contemporânea, tão globalizada, em que a internet estreita e esfacela fronteiras nacionais e reestabelece laços ideológicos e afetivos como os marcadores de identidades substitutos de categorias limítrofes como nacionalidades e nacionalismos. Pelo caráter vasto da poesia de Jason Nelson, bem como a extensão do tópico, justifica-se a interrogação dessa conclusão, que, por sua vez, poderia ser melhor lida como uma iniciação, introdução às possibilidades (inter)discursivas da poesia eletrônica e ao estudo desta como uma marca dos tempos hiper-contemporâneos.

\section{E-POETRY: THE MARK OF THE HIPER-CONTEMPORARY}

ABSTRACT: The fragmentation of paradigms and concepts of last decades caused a noticeable epistemological-subjective change on the self. This change equally came to the realm of Arts, as artists, people who are connected to the contemporary times to the level of problematizing and exposing it, created works labeled as e-poetry, a new poetry genre that's characteristic of the 21 st century, which aims to reorganize the poetic construction and the inter and intra-subjective relations. This paper aims to analyze one of these artists, Jason Nelson, demonstrating to what extent this art perceives and reflects the current times, involved in a wide technical scientific and visual diffusion. To achieve this objective, reflections of Giorgio Agamben and Jean-François Lyotard will be used when it comes to define the role of Science in the hodiern life, as the visual aspect of it.

KEYWORDS: Hiper-Contemporary, E-poetry, Post-modernity.

\section{REFERÊNCIAS}


AGAMBEN, Giorgio. "O que é o contemporâneo?". In: 0 que é o contemporâneo? E outros ensaios. Trad. Vinícius Nicastro Honesko. Chapecó, SC: Argos, 2010.

ANDRADE, Carlos Drummond de. Poesia Completa. Rio de Janeiro: Nova Aguillar, 2002.

BACON, Francis. Aforismos sobre a interpretação da natureza e o reino do homem - Livro I. In:

Paulo: Nova Cultural, 1999. Pp. 31-98. Novum Organum [1620]. Col. Os Pensadores. São Nova Atlântida. [1627]. Coleção Os Pensadores. São Paulo: Nova Cultural, 1999. Pp. 219-254.

KANT, Immanuel. Resposta à pergunta: Que é "Esclarecimento"? (Aufklärung) [1783]. In: Textos Seletos. 6‥ Petrópolis: Ed. Vozes, 2010. Pp. 63-71.

Fundamentação da Metafísica dos Costumes. Trad. Paulo Quintela. Lisboa: Ed. 70, 2007.

LÉVY, Pierre. Cibercultura. São Paulo: Editora 34, 1999.

LYOTARD, Jean-François. A Condição Pós-Moderna. 10a․ Ed. Rio de Janeiro: José Olympio, 2008.

NELSON, Jason. jason.nelson's.digital.poetry.interfaces. Disponível em <http://heliozoa.com/?p=125\#more-125>. Acesso em 10 set. 2013.

SCHIMMEL, Annemarie. The Mystery of Numbers. Nova lorque: Oxford University Press, 1993.

Texto recebido em 01/11/2013.

Texto aprovado em 29/11/2013. 